\title{
EGFR NP_005219.2:p.G796S
}

National Cancer Institute

\section{Source}

National Cancer Institute. EGFR NP 005219.2:p.G796S. NCI Thesaurus. Code C147023.

A change in the amino acid residue at position 796 in the epidermal growth factor receptor protein where glycine has been replaced by serine. 